\title{
The Epidemiological and Spatial of Diarrhea in Konawe Utara District, Indonesia
}

\author{
Ramadhan Tosepu ${ }^{1}$, Emilia Karini Puteri Merdeka ${ }^{2}$, Jumakil Jumakil ${ }^{3}$ \\ \{ramadhan.tosepu@uho.ac.id ${ }^{1}$,pigletpiaoliang@gmail.com ${ }^{2}$ \} \\ ${ }^{1}$ Faculty of Public Health, Halu Oleo University, Kendari, Indonesia \\ ${ }^{2}$ The Postgraduate program, Halu Oleo University, Indonesia \\ ${ }^{3}$ Dinas Kesehatan Kabupaten Konawe Utara, Sulawesi Tenggara, Indonesia
}

\begin{abstract}
Diarrhea is a disease that occurs when there is a change in stool consistency apart from the frequency of defecation. The risk factors mentioned above are several factors from patients who can increase the tendency for diarrhea, among others: malnutrition especially malnourished children, immunodeficiency diseases and measles sufferers, in addition to sufferers of parents' role in prevention and care of children with diarrhea, is very important. This research is a descriptive study with a retrospective approach and uses medical records to determine the description of acute diarrhea cases in Konawe Utara District in 2013-2017. Conclusion The number of cases of diarrhea sufferers in the last five years in the district of Konawe Utara shows an increase, in 2013 the number of cases of diarrhea was 1176 cases and decreased in 2014 as many as 1399 cases, but in 2015 to 2017 it was seen increasing with a total of 1313 cases.
\end{abstract}

Keywords: Diarrhea, Age, Gender, Southeast Sulawesi, Indonesia

\section{Introduction}

Diarrhea is a public health problem in several regions in Indonesia. Control of this disease has long been carried out. Diarrhea is a condition where there is a change in density and character of water feces and feces issued three or more times per day [1],[2]. Diarrhea occurs due to digestion of E. Colli bacteria to food. These bacteria are very happy to be in human feces, dirty water, and stale food. To prevent the occurrence of diarrhea, the food given to children must be hygienic [3].

Diarrhea is a common condition characterized by an increase in the frequency of bowel movements and increased liquidity from feces. Although acute diarrhea can usually heal itself, it can worsen and cause dehydration that exacerbates, which can cause abnormal blood volume, decreased blood pressure, and damage to the kidneys, heart, liver, brain and other organs [4]. Acute diarrhea is the leading cause of infant mortality worldwide [5].

According to the World Health Organization and UNICEF, there are around 2 million cases of diarrhea throughout the world each year and 1.9 million children younger than five years die of diarrhea every year, especially in developing countries. This amounts to $18 \%$ of all deaths of children under the age of 5 and means that $>5000$ children die every day due to diarrhea [1]. This death from the diarrheal disease usually occurs early in infancy and children with severe 
dehydration [6],[7]. Dehydration itself is defined as loss of water and salt or extracellular fluid. The most common cause of babies is diarrhea caused by viral and bacterial infections.

The incidence and period prevalence of diarrhea for all age groups in Indonesia are 3.5 percent and 7.0 percent. The five provinces with the highest incidence and prevalence of diarrhea were Papua (6.3\% and 14.7\%), Sulawesi Selatan (5.2\%) and 10.2\%), Aceh (5.0\% and 9.3\%), Sulawesi Barat (4.7\% and $10.1 \%$ ), and Sulawesi Tengah (4.4\% and $8.8 \%)$. The incidence of diarrhea in the toddler age group in Indonesia is 6.7 percent. The five provinces with the highest rate of diarrhea were Aceh (10.2\%), Papua (9.6\%), DKI Jakarta (8.9\%), Sulawesi Selatan (8.1\%), and Banten (8.0\%) [8].

\section{Methods}

Konawe Utara with an expansion of the capital Wanggudu. Konawe Utara formed under Act No. 13 of 2007 regarding the establishment of Level II Regional District in the Province of Southeast Sulawesi. Geographically Konawe Utara located in the northern Equator, across from north to south between $02^{0} 97^{\prime}$ and $03^{\circ} 86^{\prime}$ south latitude, stretching from west to east between $121^{\circ} 49^{\prime}$ and $122^{\circ} 49^{\prime}$ East longitude.

Data on diarrheal diseases was obtained from the Konawe Utara Health Office. This research is a descriptive study with a retrospective approach and uses secondary data (medical records) to determine the description of acute diarrhea cases in Konawe Utara district in 2013-2017. Spatial uses the Geographic Information System approach. Data analysis used spatial-temporal modeling analysis describing the development of diarrheal disease in Konawe Utara District in 2013 - 2017. Stages of Data Analysis namely Data collected and presented in the form of tables and graphs, Data on cases of diarrhea per district during 2013-2017 were included in attribute data map of Konawe Utara district, then processed using the Geographic Information System application, ArcGIS 10.2, Processing and analysis of data resulted in a plan of the development of diarrhea cases in Konawe Utara district in 2013-2017.

\section{Results}



Figure 1. Trends of diarrhea in Konawe Utara district, Indonesia 
Diarrhea cases in Konawe Utara district increased in October in 2013. Furthermore, the peak of diarrhea in 2014 and 2016 occurred in January. Continued in 2015 the highest case in November, and in 2017 the highest incidence of diarrhea occurred in March (Figure 1).



Figure 2. Distribution of diarrhea by gender Konawe Utara district, Indonesia

Diarrhea cases by gender also illustrate an increase in the number of cases of diarrhea every year. The proportion of diarrhea incidence in men and women is different where it is clear that male sufferers are higher than the percentage of female sufferers. The number of cases of diarrhea in men in 2013 was 954 cases while women as many as 822 cases and a decrease in 2014 as many as 783 cases for male and female sex as many as 616 cases, but from 2015 to 2017 there was an increase in the number of cases diarrhea as many as 695 cases for male and female sex as many as 618 cases (Figure 2).

Diarrhea cases attack all regions of the Konawe Utara district. Based on data on the number of diarrhea cases illustrates an increase in cases every year. The number of diarrhea cases in 2013 was 1776 cases of which 13 sub-districts were in the Konawe Utara district. Lembo Sub-district ranks first with a total of 726 cases, then Molawe Sub-district is 293 and Sawa Sub-district has 200 cases of diarrhea. In 2014 there was a decrease in the number of cases of diarrhea, which were as many as 1399 cases but from 2015 to 2017 there was an increase in cases of 1313 cases of diarrhea, of which at Lembo Sub-district ranks first with a total of 302 cases, then kec. Asera Subdistrict as many as 150 cases and Motui Sub-district as many as 134 cases (Figure 3). 


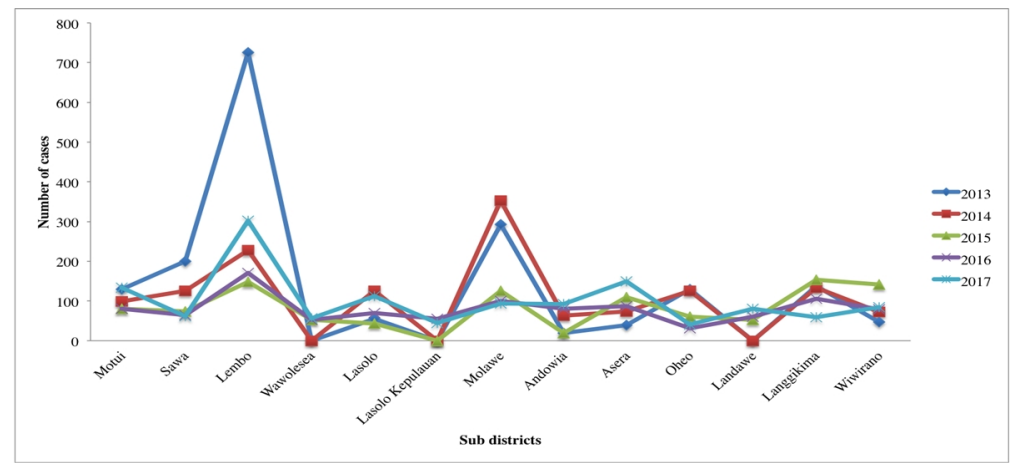

Figure 3. Cases of diarrhea by sub-districts in Konawe Utara district, Indonesia

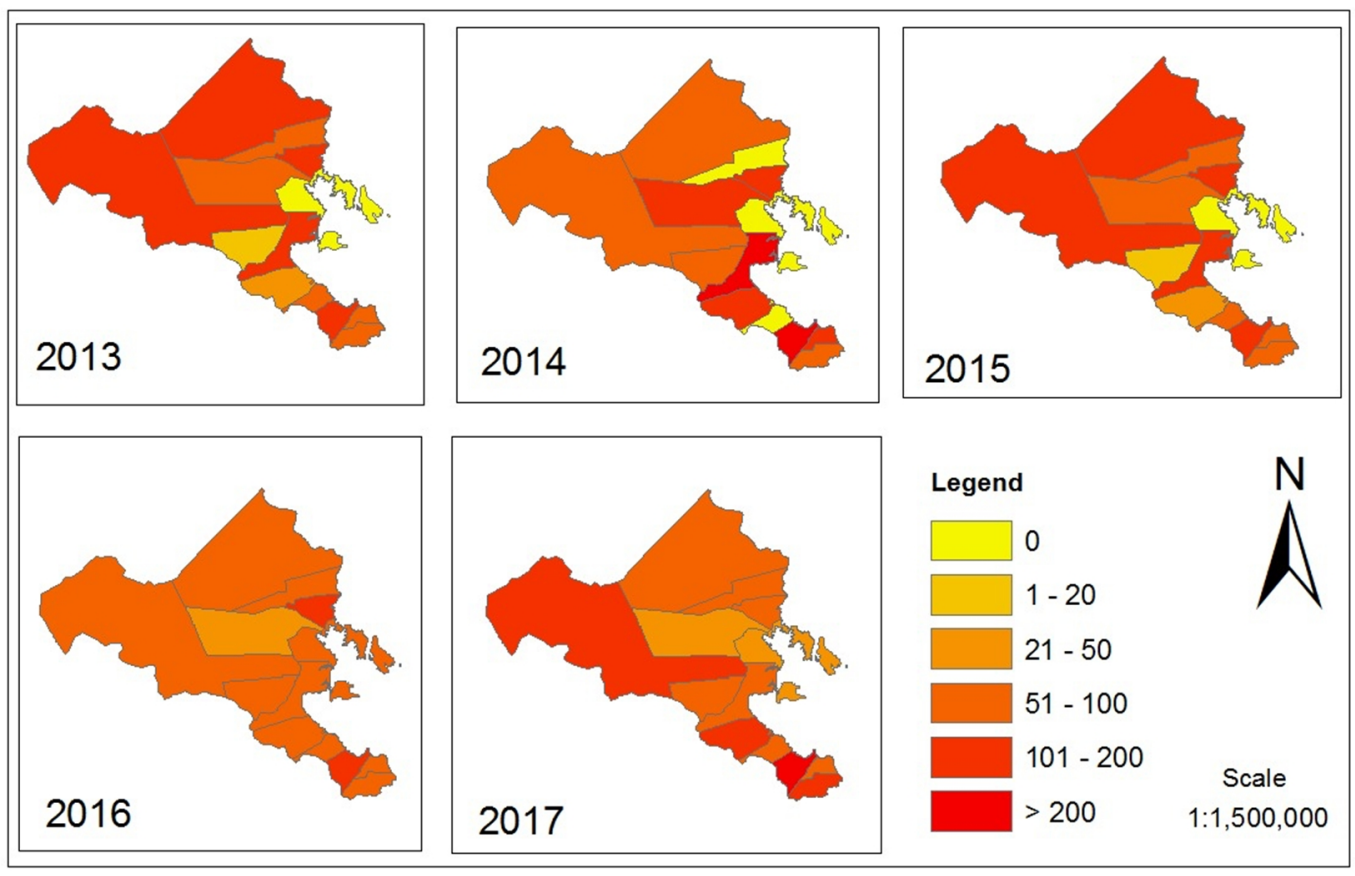

Figure 4. Spatial of the diarrhea cases in Konawe Utara district, Indonesia

In figure 4 shows that there are several regions with high diarrhea with some cases between 101-200 (Lembo Sub-district), in this sub-district, there is always diarrhea from 2013 to 2017. Meanwhile in the sub-district of Oheo diarrhea is high (101-200). 


\section{Discussion}

The thing that causes a person to get diarrhea easily is the poor behavior of the community and poor environmental sanitation [9]. Diarrhea can be fatal if not taken seriously. There are several factors related to the incidence of diarrhea, namely inadequate supply of clean water, water contaminated by feces, lack of hygiene facilities, personal hygiene, and poor environment, and improper food preparation and storage [10].

Many factors that can directly or indirectly be the driving factor for the occurrence of diarrhea, consisting of elements of agent, host, environment, and behavior [11]. Host factors that cause increased vulnerability to diarrhea, including, malnutrition, measles, and immunodeficiency [12],[13]. The most dominant environmental factor is the provision of clean water and sewage disposal; these two factors will interact together with human behavior [10]. If environmental factors are unhealthy because they are contaminated with diarrhea germs and accumulate with unhealthy human behavior, transmission of diarrhea can easily occur [14].

\section{Conclusion}

The number of cases of diarrhea sufferers in the last five years in the district of Konawe Utara shows an increase, in 2013 the number of cases of diarrhea was 1176 cases and decreased in 2014 as many as 1399 cases, but in 2015 to 2017 it was seen increasing with a total of 1313 cases. Diarrhea in the northern Konawe district is a disease that needs serious attention. Although cases of this disease occur lucratively, prevention is necessary so that the number of cases of the disease can be reduced.

\section{Reference}

[1] W. H. Organization, "The treatment of diarrhoea.", 2005.

[2] F. R. Velázquez, H. Garcia-Lozano, E. Rodriguez, Y. Cervantes, A. Gómez, M. Melo, et al., "Diarrhea morbidity and mortality in Mexican children: impact of rotavirus disease," The Pediatric infectious disease journal, vol. 23, pp. S149-S155, 2004.

[3] T. T. Kramer, J. G. Nagy, and T. A. Barber, "Diarrhea in captive mule deer fawns attributed to Escherichia coli," The Journal of Wildlife Management, pp. 205-209, 1971.

[4] C. G. Victora, J. Bryce, O. Fontaine, and R. Monasch, "Reducing deaths from diarrhoea through oral rehydration therapy," Bulletin of the World Health Organization, vol. 78, pp. 1246-1255, 2000.

[5] M. Kosek, C. Bern, and R. L. Guerrant, "The global burden of diarrhoeal disease, as estimated from studies published between 1992 and 2000," Bulletin of the world health organization, vol. 81, pp. 197-204, 2003.

[6] W. A. Petri, M. Miller, H. J. Binder, M. M. Levine, R. Dillingham, and R. L. Guerrant, "Enteric infections, diarrhea, and their impact on function and development," The Journal of clinical investigation, vol. 118, pp. 1277-1290, 2008.

[7] E. Lasch, Y. Abed, A. Guenina, N. Hassan, I. A. Abu, and K. Abdallah, "Evaluation of the impact of oral rehydration therapy on the outcome of diarrheal disease in a large community," Israel journal of medical sciences, vol. 19, pp. 995-997, 1983.

[8] B. Penelitian, "Riset kesehatan dasar (Riskesdas) 2013," Lap. Nas, pp. 1-384, 2013. 
[9] A. A. Langgesa, R. Tosepu, H. Lestari, D. S. Effendy, P. Asfian, H. Bahar, et al., "RRelated Knowledge And Attitude Of The Use Of Antibiotics In Patients With Diarrhea In Kendari Indonesia," Public Health of Indonesia, vol. 1, 2015.

[10] V. Curtis and S. Cairncross, "Effect of washing hands with soap on diarrhoea risk in the community: a systematic review," The Lancet infectious diseases, vol. 3, pp. 275-281, 2003.

[11] S. Bunnapradist, L. Neri, W. Wong, K. L. Lentine, T. E. Burroughs, B. W. Pinsky, et al., "Incidence and risk factors for diarrhea following kidney transplantation and association with graft loss and mortality," American Journal of Kidney Diseases, vol. 51, pp. 478-486, 2008.

[12] E. Halmos, J. Muir, J. Barrett, M. Deng, S. Shepherd, and P. Gibson, "Diarrhoea during enteral nutrition is predicted by the poorly absorbed short $\square$ chain carbohydrate (FODMAP) content of the formula," Alimentary pharmacology \& therapeutics, vol. 32, pp. 925-933, 2010.

[13] K. H. Brown, "Diarrhea and malnutrition," The Journal of nutrition, vol. 133, pp. 328S-332S, 2003.

[14] G. P. Root, "Sanitation, community environments, and childhood diarrhoea in rural Zimbabwe," Journal of health, population and nutrition, pp. 73-82, 2001. 